\title{
The Development of Textbook Based Approach To Teach Scientific Literacy At $5^{\text {th }}$ Grade
}

\author{
Sri Utaminingsih, Muslimin Ibrahim, Suryanti \\ Basic Education Program \\ Universitas Negeri Surabaya \\ Surabaya, Indonesia \\ taminaurah.18@gmail.com
}

\begin{abstract}
This research aimed to produce textbook based on scientific strategy and to describe validity, practicality, and effectiveness of textbook as well as teach scientific literacy skills of students on heat and displacement material. This was developmental research (Research and Development). This research was the development of scientific strategy-based textbook that was trial-tested for elementary school $5^{\text {th }}$ Gading I Surabaya with one group pretest-postest design. The research instrument including form of sheet validation, observation sheet of implementation lesson plans, and science literacy test. The textbook based on scientific strategy was valid with mode in terms of components. The practicality was showed with lesson plan by $92.66 \%$. The effectiveness was resulted with a percentage of $90 \%$ of students pass and got positive responses of learning. Based on this data it can be concluded that textbook was valid, practical, and effectiveness, hence it can to be used to teach science literacy skills.
\end{abstract}

Keywords-textbook; science literacy skills; heat and displacement

\section{INTRODUCTION}

Based on regulation of Ministry of science and cultural of Indonesian Republic No. 20 of 2016 concerning Graduates Competency Standards explained that the competence of graduates which must be mastered by graduate students pesetas Elementary School consists of three dimensions: attitudes, knowledge, and skills. Based on competency standards, then the learning process in schools should be done interactively, inspiring, fun, able to motivate students so that students actively participate and provide enough space for innovation, creativity, and independence. So that it is able to give students the opportunity to learn according to their talents and interests as well as psychological. Hence, students can compete in facing the development of technology and science in the 21 st century. National Science Teachers Association states support 21st century skills that cover the subject of knowledge, skills in learning and innovation, information and media and technology skills, life skills and career skills, adaptability, complex communication or social skills, problem solving, self-development and systematic thinking [1]. The competence should be the focus in the world of education in Indonesia is the critical thinking ability to solve problems, creativity, communication, and collaboration. These skills to be possessed by the students for the challenges of the future development [2]. As a great nation, the cultural development of life skills of literacy as a prerequisite for the 21 st century in Indonesia is a must, which one of them is integrated education, from family, school and community levels. World Economic Forum in 2015 stated that the acquisition of the six basic literacy those are literacy, numeracy, science, digital, finance, and culture is very important not only for students but also for parents and all citizens. [3] Most recent definitions of science or scientific literacy depend on these steps of the scientific method, and therefore, science as a process.

Science literacy is an important part that needs to be mastered students to achieve growth of capital in the $21 \mathrm{st}$ century. [4] Science literacy is related to goals of science education, and scientific literacy is related to approaches to achieving science literacy. Literacy science is a person's ability to understand the concept or knowledge about science and its applications are owned in problem-solving in everyday life based on evidence and scientific data [5]. Literacy science is not only the ability of how to understand the knowledge, but also with regard to how to understand the various aspects of the process of science, as well as the applicability of these two things in the reality faced by the students, either personally, socially and globally [6].

Science literacy needs to be taught to students as it relates to understanding the knowledge of students and the application of knowledge in everyday life with regard to decision-making on the environment, health, economic, and other problems encountered in public life. [7] In addition, science literacy is thought to have a very important place in terms of improving the level of development of the society by making individuals more able to understand their environment, to establish a relationship between science and everyday life, to make their lives more meaningful, to contribute to scientific culture and to take an active role in society. Efforts by the government through the Literacy 
Movement School is done because of the low competence of students in Indonesia in three areas: math, science, and reading [2]. As the data from the study results in PIRLS (Progress of International Reading Literacy Study) in 2011 showed that the ability to understand the reading by Indonesian students is under the international average.

PISA 2015 also reported high levels of science literacy of students in Indonesia is very low and is below the OECD average. The results of scientific literacy ability scores obtained by students in Indonesia is 403 [5]. Difficulties experienced by students is the ability of students to make connections between scientific concepts and phenomena in daily life. Material science is regarded as a collection of theories that are memorizing it. This is one of the causes of low achievement of students' science literacy competence that puts Indonesia Indonesian students are under the international average score based on data PISA and TIMSS.

Another fact that was found was learning outcomes for fifth-grade science students at Gading elementary school I still low. This is evident from the number of students who scored below the minimum completeness criteria on natural science subjects. Taken from 40 students only 10-11 students are able to reach a value above minimum completeness criteria. So we might say almost $75 \%$ of students score below the minimum completeness criteria. The low yield is due to the learning process of students learning more emphasis on students' knowledge of the material being studied and are rote so that students had difficulty answering questions that require higher-level thinking involving the processing and scientific attitude. [8] The science process skills involve skills that require more complex experiences such as the ability to observe that we develop and utilize naturally even in our very early ages, in addition to comparison skills, data gathering, data interpretation and ability to hypothesize.

From the facts obtained by researchers through observation and interviews with classroom teachers Gading I elementary school Surabaya related to the textbook do in school and learning activities Natural science in schools obtained some information among which textbooks are used by teachers in the classroom is a book thematic issued by ministry of science and cultural of Indonesian Republic that and also there are no examples of books that teach science literacy in elementary schools. So it is necessary for the development of teaching materials that can increase the scientific literacy of students. Developed teaching materials adapted to the nature of science teaching and adapted to the character of students in the material heat and movements. That's because science is essentially a product, process, and application. Natural Science as a product composed of law, principles, procedures, theories, concepts, facts, and information. Meanwhile, as a process, Natural Science is a process that is used to study the object of study, discover and develop the products of science and as an application [9]. So to teach students scientific literacy should be learning like scientists attack.
Carin and Sund define science as knowledge in the form of data collection observation and experiment systematically arranged, organized and applied universally to the main elements of the attitudes, processes, products, and applications [10]. So to teach science must encompass all dimensions contained natural science charge. As research Ashari and Hartati (2015) explains that based on the research results the literacy skills of students science seventh-grade on competence aspects and aspects of knowledge increased after the implementation of a scientific study on the matter of environmental pollution [11]. The development of curriculum-based learning tools to train 2013 Science literacy seventh-grade student in energy materials [12]. In the Online International Journal of Primary Education stated that learning by developing science literacy activities of students in the learning of science and technology can improve learning outcomes of students [12]. A scientific approach is an approach that is centered on students. Where the student activities consist of activities to observe, ask, to reason, to try and form a network. By conducting a series of activities is then expected to train the ability of students to think critically and solve a problem in a systematic way in their lives By increasing high-level thinking skills, students are expected to understand the concept of material optimally and are able to obtain optimal learning outcomes.

The scientific approach with regard to the scientific method or scientific method scientific method generally involves observation is needed in the formulation of hypotheses or data collection [13]. The learning process is constructed so that the students can play an active role in constructing the concept, law, or the principle of using the stage observe (as the identification of the problem), to formulate the problem, formulating a hypothesis, collecting data with a wide kinds of techniques, analyzing data, drawing conclusions and communicate the concept, the findings of law or principle [14]. In addition, Daryanto (2013) also explains that the scientific approach (scientific) used in the process of learning to the curriculum in 2013 for all levels of education in the implementation. The step-bystep scientific approach used in the learning process is extracting information through observation, questioning, experimentation, data processing or information, presentation of data or information.

Heat is a form of energy that moves from objects at high temperature to a lower temperature object [10]. Calorific material characteristics and the displacement is highly related to daily life, so the concept of the displacement of heat and need to be taught to students by encouraging students to become directly involved in the learning activities and experiments. The use of teaching materials based on scientific approach can be used in the event where the learning process students are required to be active in doing, observation, experiment, reason and communicate the activities that have been carried out. Science teaching as a way of thinking was not effective as the teachers did not 
link the scientific concepts in any meaningful or developmental way with what the learners had already experienced in their everyday live [15]. By leveraging the scientific learning students are actively engaged and challenged to experiment during the learning. Then the literacy ability of students in materials science and the displacement of heat can be achieved in accordance with the expected results.

Teaching materials are an important element of the curriculum. That's because the teaching materials is the content syllabus framework specified direction and objectives of a content and language learning experience. Teaching materials must have a full load of competencies which students will learn in learning activities [12]. Various learning resources and materials collected and arranged systematically the teaching materials [13]. The teaching materials are used to build scientific literacy should be developed based on specific criteria in order to get quality results. A material quality is said if fulfilled aspects of quality such as validity, practicality, and effectiveness [14]. So that the quality of teaching materials can be said is that if a valid teaching material, practical to use and effective in achieving their learning competencies. In science learning teaching materials developed should be in accordance with the nature of science teaching in elementary schools.

\section{METHOD}

This research is the development by using the 4D model, which is based on the Scientific development of teaching materials for elementary school students with Heat and The Displacement.

Subjects in this study is a scientific-based teaching materials to teach science literacy students in fifth-grade at elementary school Gading I Surabaya on even-numbered semester year 2017/2018.

The study design using a design research and development research and development belong to Thiagarajan, Semmel, and Semel (1974) called 4D consists of four stages: determination (Define), the design (Design), development (Develop), and Deployment (Disseminate) [20].

This model was chosen because relevant curriculum scientific 2013 that approach, but it is a development model 4D has a clear and coherent stage in its development then it will be easy to follow.

Phase defining an initial stage in the development of 4D aimed to establish learning needs by analyzing the goals and limits of the subject matter that will be developed. These stages include needs analysis, analysis of students, task analysis, procedural analysis, analysis of the concept and formulation of learning objectives.

The design phase is done after the definition phase. This stage aims to prepare teaching materials and other learning tools oriented scientific approach that can be used in science teaching in elementary schools. The design phase consists of several steps include devising tests, media selection, the selection format, and a preliminary draft.

The next stage is the stage of development aiming to get the final shape of a scientific approach based teaching materials were developed along with its supporting device. The development was conducted on the materials, syllabus, lesson plans, students' activity sheet and Tests Literacy Science on material for heat and displacement consisting of expert validation, (performed by two validator experts to get feedback, improvement of teaching materials and produce teaching material

Data of these validation results presented in tabular form recap validation of teaching materials to facilitate data analysis), the tests performed using the design of the study one group pretest-posttest.

This study used an instrument in the form of sheets validation study the feasibility of the device, the observation sheet Implementation of lesson plans and science literacy test. In addition, the validation is also carried out on The Lesson plans, Students Activity Sheet, and Implementation of science literacy test as supporting learning. Further validation of teaching materials and learning tools supporting analyzed using qualitative descriptive analysis techniques. Analysis of the results of the validation of teaching materials, Implementation of learning and literacy test results used the following technique.

\section{A. Analysis of The Results of The Validation}

Instrument reliability validity of teaching materials developed expressed as a percentage of conformity with the (1) as the [16].

$$
\text { Percentage of Agreement } \mathrm{R}=\left\{1-\frac{A-B}{A+B}\right\} \times 100 \%
$$

Information:

$\mathrm{R}=$ Reliability

$\mathrm{A}=$ Frequency aspects observed by the assessors who provide high frequency.

$\mathrm{B}=$ Frequency aspects observed by the assessors are on low frequencies.

The instrument is said to be good if it has a correlation coefficient of reliability of $>75 \%$ or 0.75 [17].

TABLE I. CATEGORIZATION CRITERIA VALIDITY INSTRUCTIONAL MATERIALS [18]

\begin{tabular}{ccc}
\hline Interval Scores & Category & Information \\
\hline $3.6 \leq \mathrm{VS}<4$ & very Valid & Can be used without revision \\
\hline $2,6 \leq \mathrm{VS}<3.5$ & Valid & Can be used with little revision \\
\hline $1.6 \leq \mathrm{VS}<2.5$ & Less Valid & $\begin{array}{c}\text { Can be used with many } \\
\text { revisions }\end{array}$ \\
\hline $1.0 \leq \mathrm{VS}<1.5$ & Invalid & $\begin{array}{c}\text { Can not be used, still need } \\
\text { revision }\end{array}$ \\
\hline
\end{tabular}


Description: VS $=$ Validation Score

\section{B. Analysis of Learning Implementation}

In general, the calculation of the percentage of RPP implementation measured by using the formula (2).

$$
P=\frac{\sum K}{\sum N} x 100 \%
$$

$$
\begin{aligned}
& \text { Information: } \\
& \begin{array}{ll}
\mathrm{P} & =\text { Score of RPP's implemented } \\
\Sigma \mathrm{K} & =\text { Total aspect implemented } \\
\Sigma \mathrm{N} & =\text { The total number of aspects observed. }
\end{array}
\end{aligned}
$$

\section{Analysis of Science Literacy Test Results}

Analysis of scientific literacy test is obtained based on the completeness of scientific literacy. The success of the students said completely when getting value reaches the minimum completeness criteria in schools; 75. Mastery learning per student at any scientific literacy indicators calculated using formula (3). Science literacy test results is completed as $\geq 75 \%$ of students achieve mastery indicator.

Completeness indicator $=\frac{\sum \text { students that achieve the indicator }}{\sum \text { students }} \times 100 \%$

\section{RESULTS AND DISCUSSION}

\section{A. Results Validation of Teaching Material}

This study aims to produce a product in the form of teaching materials based on scientific approaches and supporting learning device consisting of a syllabus, lesson plan, Students Activity Sheet, and scientific literacy test.

The results of the validation of teaching materials that students can be seen briefly in Fig. 1 .

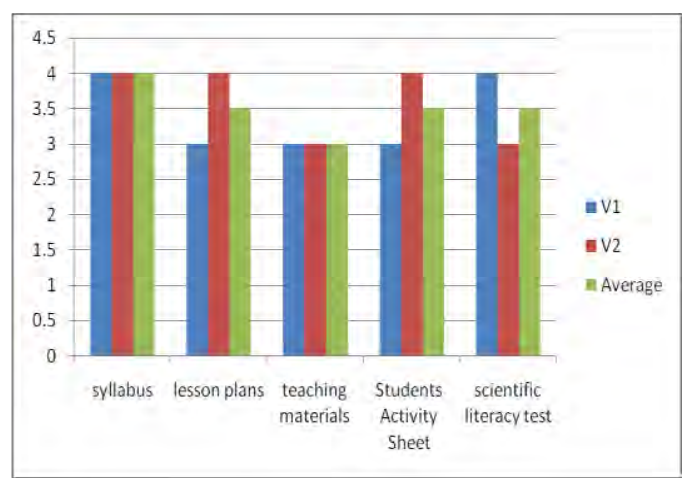

Fig. 1. Recap Results Validation of Teaching Materials and Learning Tool

In Fig. 1, it is known that in general, the average yield validation teaching materials are in the range from 2.6 to 3.5 with a valid category so that used unless the results of the validation syllabus that has a 4.00 in score categorized as very feasible to use. The results of the validation lesson plans, teaching materials, and scientific literacy test had an average score of 3.5 with the same ie both categories. The tests can be used but it requires a bit of revision. Revisions were made based on suggestions and feedback from the validator. Results of the reliability of the two validators can be seen in the Table II.

TABLE II. RESULTS OF VALIDATION RELIABILITY INSTRUCTIONAL MATERIALS AND DEVICES

\begin{tabular}{cccc}
\hline Aspect Builds & \multicolumn{3}{c}{ Appraisal } \\
\hline S1 & V2 & Reliability \\
\hline Lesson plan & 3 & 4 & $100 \%$ \\
\hline Teaching materials & 3 & 3 & $85.71 \%$ \\
\hline Students activity sheets & 3 & 4 & $100 \%$ \\
\hline Literacy tests & 4 & 3 & $85.71 \%$ \\
\hline Mode & & & $85.71 \%$ \\
\hline
\end{tabular}

From the table II, it can be seen that the results of two lecturers' validation reliability of teaching materials and supporting devices currently on $85.71 \%$ and $100 \%$.

\section{B. Results of Practicality Learning}

The practicality of instructional materials is demonstrated by the implementation of learning by using teaching materials based on a scientific approach along with obstacles during learning. Results of the implementation of learning can be seen in table III below.

From the table III, it can be seen that the average observation two learning by observers at study 1 by $86.91 \%$, amounting to $92.27 \%$ The learning 2 and the learning 3 by $98.81 \%$. In all average yield of 1 to 3 are learning the value of $92.66 \%$ which indicates that learning very successfully.

During the learning process by using scientific approach in the classroom there are some obstacles that hinder the learning process. One of the obstacles is the utilization of

\begin{tabular}{|c|c|c|c|}
\hline \multirow{2}{*}{$\begin{array}{l}\text { Implemented (Lesson } \\
\text { Plan) }\end{array}$} & \multicolumn{3}{|c|}{ Percentage } \\
\hline & P 1 & $\mathbf{P} 2$ & $\begin{array}{c}\text { The } \\
\text { mean }\end{array}$ \\
\hline Lesson 1 & $89.29 \%$ & $84.52 \%$ & $86.91 \%$ \\
\hline learning 2 & $92.86 \%$ & $91.67 \%$ & $92.27 \%$ \\
\hline Lesson 3 & $98.81 \%$ & $98.81 \%$ & $98.81 \%$ \\
\hline On average Overall & & & $92.66 \%$ \\
\hline
\end{tabular}
time allocation that exceeds planning. For that the teacher must manage the time well and do the mature planning so that learning can run well.

TABLE III. LEARNING IMPLEMENTATION 
C. Results of Effectiveness of Teaching Material

TABLE IV. THE ABILITY OF SCIENCE LITERACY

\begin{tabular}{|c|c|c|c|c|c|c|c|}
\hline \multirow{2}{*}{$\begin{array}{c}\text { No } \\
\text {. }\end{array}$} & \multirow{2}{*}{$\begin{array}{c}\text { Nam } \\
\text { e }\end{array}$} & \multicolumn{4}{|c|}{ Value } & \multirow{2}{*}{$\begin{array}{c}\text { Gain } \\
\mathrm{N}-\end{array}$} & \multirow{2}{*}{$\begin{array}{l}\text { Cate } \\
\text { gory }\end{array}$} \\
\hline & & $\begin{array}{l}\text { Pre- } \\
\text { test }\end{array}$ & $\begin{array}{c}\text { Completen } \\
\text { ess }\end{array}$ & $\begin{array}{c}\text { Post- } \\
\text { test }\end{array}$ & $\begin{array}{c}\text { Complete } \\
\text { ness }\end{array}$ & & \\
\hline 1. & DIN & 20 & Incomplete & 80 & complete & 0.75 & High \\
\hline 2. & GIT & 20 & Incomplete & 70 & $\begin{array}{c}\text { Incomple } \\
\text { te }\end{array}$ & 0.63 & $\begin{array}{l}\text { mod } \\
\text { erate }\end{array}$ \\
\hline 3. & FAI & 30 & Incomplete & 90 & complete & 0.75 & High \\
\hline 4. & LIN & 40 & Incomplete & 90 & complete & 0.63 & $\begin{array}{l}\text { mod } \\
\text { erate }\end{array}$ \\
\hline 5. & ALI & 30 & Incomplete & 90 & complete & 0.75 & High \\
\hline 6. & SON & 30 & Incomplete & 90 & complete & 0.75 & High \\
\hline 7. & ZAN & 40 & Incomplete & 90 & complete & 0.63 & $\begin{array}{l}\text { mod } \\
\text { erate }\end{array}$ \\
\hline 8. & IWN & 50 & Incomplete & 90 & complete & $0: 50$ & $\begin{array}{l}\text { mod } \\
\text { erate }\end{array}$ \\
\hline 9. & LAV & 50 & Incomplete & 90 & complete & $0: 50$ & $\begin{array}{l}\text { mod } \\
\text { erate }\end{array}$ \\
\hline 10. & 1QB & 60 & complete & 100 & complete & $0: 50$ & $\begin{array}{l}\text { mod } \\
\text { erate }\end{array}$ \\
\hline \multicolumn{2}{|c|}{ Average } & 36 & & 88 & & & \\
\hline \multicolumn{2}{|c|}{$\begin{array}{c}\text { Complete- } \\
\text { ness }\end{array}$} & 75 & & 75 & & & \\
\hline \multicolumn{2}{|c|}{$\begin{array}{c}\text { Students } \\
\text { who } \\
\text { Completed }\end{array}$} & & $0 \%$ & & $90 \%$ & & \\
\hline \multicolumn{2}{|c|}{$\begin{array}{c}\text { Students } \\
\text { who } \\
\text { Incomplete }\end{array}$} & & $100 \%$ & & $10 \%$ & & \\
\hline
\end{tabular}

The effectiveness of instructional materials is indicated by the results of scientific literacy test scores of students and student response to learning. Rate science literacy students performed prior learning (pretest) and after learning implemented (post-test). Pretest be used to determine the ability of early students prior to learning. Posttest aims to determine the ability of students following a learning process. The results of the pretest, posttest, and N-Gain is seen in Table IV.

Based on the scientific literacy test results table above can be seen that the percentage of completeness learning from the results of the pre-test $100 \%$ of students do not reach minimum completeness criteria means students speckle thoroughly studied. While on the posttest results showed $90 \%$ of students scored minimum completeness criteria means that students pass the study and only $10 \%$ of students who do not pass the study. This shows that learning by using scientific teaching materials can be used effective.

\section{CONCLUSION}

Based on the analysis and discussion of the results of this study concluded that: (1) based teaching materials and their scientific approach developed learning tools are supporting a valid, practical and effective way to advocate literacy skills of students in materials science and displacement heat; (2) the use teaching materials based on Scientific approach can improve students' sacientific literacy; and (3) students respond positively to learning by using teaching materials based on a scientific approach.

\section{REFERENCES}

[1] National Science Teachers Association (NSTA). (2011). NSTA Position statement: quality science education and 21 st-century skills

[2] Kemdikbud. (2017). Materi pendukung literasi baca tulis gerakan literasi nasional. Jakarta: Kementerian Pendidikan dan Kebudayaan Republik Indonesia.

[3] Klucevsek, K. (2017). "The intersection of information and science literacy”. Journal Communications in Information Literacy, 11(2), 354-365.

[4] Liu, X. (2009). "Beyond science literacy: Science and the public". International Journal of Environmental \& Science Education, Vol. 4, No. 3, 301-311.

[5] Holbrook, J., \& Rannikmae, M. (2009). "The Meaning of Scientific Literacy International”. Journal of Environment \& Science Teaching, 4(3).275-278.

[6] Deboer, G.E. (2000) "Scientific literacy: Another look at its historical and contemporary meanings and its relationship to science education reform. Journal of Research in Science Teaching, 37.No.6.

[7] Çelik, C. and Şendil C. (2017). "Intercultural adaptation and validity study: universal science literacy Scale (USLS)". Universal Journal of Educational Research 5(12): 2125-2136.

[8] Yumuşak, G. K. (2016). "Science process skills in science curricula applied in Turkey". Journal of Education and Practice Vol.7, No.20, 2016

[9] OECD. (2015). Assessment and analitycal framework mathematicts, raeding, science, problem solving and financial literacy. S.1: OECD Publishing.

[10] Wisudawati, A.W. (2013). Metodologi pembelajaran IPA sesuai kurikulum 2013. Jakarta: Bumi Aksara.

[11] Ashari, A. and Hartati, R. (2015). "Profil peningkatan kemampuan literasi sains siswa melalui pembelajaran saintifik". Jurnal Ilmiah Pendidikan Fisika Al-BiRuNi 04 (2) (2015) 179-191.

[12] Gueluer, E. and Kesercioglu, T.(2012). "The effect of using Activities improving scientific literacy on student's achievement in science and technology lesson. International Online Journal of Primary Education, Volume:1.

[13] Inzanah. (2014). Pengembangan perangkat pembelajaran IPA berbasis kurikulum 2013 untuk melatih literasi sains peserta didik SMP. Unesa: Tesis yang Tidak Dipublikasikan.

[14] Sani, Abdullah Ridwan. 2014. Pembelajaran Saintifik untuk Implementasi Kurikulum 2013. Jakarta: Bumi Aksara.

[15] Set, B., Joanne, H. and Daniel, O. (2017). "An Investigation into how grade 5 teachers teach natural science concepts in three western cape primary schools". World Journal of Education Vol. 7, No. 1.

[16] Trianto. (2013). Mendesain model pembelajaran inovatif, progresif, konsep, landasan, dan implementasinya pada kurikulum tingkat satuan pendidikan (KTSP). Jakarta: Kencana Prenada Media Group.

[17] Prastowo, Andi (2013). Panduan kreatif membuat bahan ajar inovatif. Jogjakarta: Diva Press.

[18] Daryanto. (2014). Pendekatan pembelajaran saintifik kurikulum 2013. Yogyakarta: Penerbit Gama Media.

[19] Nieveen, N. (1999). Prototyping to reach product quality. London: Kluwer Academic Publisher.

[20] Thiagarajan, Semmel, DS \&Semmel M.I. (1974). Instructional development for training teacher of exceptional children. A Sour Book. Blomington: Center for Innovation on Teaching the Handicapped.

[21] Ratumanan, T.G. \& Laurens T. (2011). Penilaian hasil belajar pada tingkat satuan pendidikan Edisi 2. Surabaya: UNESA Press.

[22] Ibrahim, M. (2005). Assesmen berkelanjutan konsep dasar, tahapan, pengembangan, dan contoh. Surabaya: Unesa University Press.

[23] Borich, G.D. (1994). Observation skills for effective teaching. New York: Macmillan Publishing. 